\title{
OPTOMETRINĖS PRIEŽIŪROS PASLAUGŲ ORGANIZAVIMO IR PRIEINAMUMO LIETUVOJE YPATUMAI
}

\author{
Vaida Kačergienė, Faustas Stepukonis, Sigutė Norkienė \\ Klaipèdos universiteto Sveikatos mokslu fakulteto Visuomenès sveikatos katedra
}

Raktažodžiai: asmens sveikatos priežiūra, optometrija, optometrininkas, optometrinė priežiūra, optometrijos paslaugos.

\section{Santrauka}

Darbo tikslas. İvertinti optometrinès priežiūros paslaugų organizavimo ir prieinamumo Lietuvoje ypatumus.

Darbo metodika. Tyrimui atlikti naudotas instrumentas - elektroninis klausimynas, ị kurị respondentams buvo išsiųsta nuoroda elektroniniu paštu. Tiriamuju imtị (134 respondentai) sudarè optometrininkai, registruoti Lietuvos optometrininkų asociacijoje. Iš viso buvo užpildytos ir pateiktos analizei 86 respondentu anketos, t.y. grị̌tamumas sudarè $64,2 \%$. Pusès respondentų $(48,8 \%)$ nurodytas darbo stažas buvo $6-10$ m. Daugumos respondentu $(82,6 \%)$ nurodyta pagrindinè darbo vieta - didmiestis (Vilnius, Kaunas, Klaipèda), o daugiau nei $95 \%$ - teikia paslaugas privačiame sektoriuje (t.y. optikos salonuose). Statistinè duomenų analizė atlikta naudojant SPSS programinę įrangą (23.0 versija). Rezultatų skirtumai laikyti statistiškai reikšmingais, kai $\mathrm{p}<0,05$.

Rezultatai. Nustatyta, kad Lietuvoje dažniausiai teikiamos optometrinès priežiūros paslaugos yra kontaktinių lęšių rūšies parinkimas ir pritaikymas $(97,7 \%)$, regos korekcijos kortelių kontaktiniams lęšiams ir akiniams išrašymas (atitinkamai 97,7\% ir 96,5\%), subjektyvios refrakcijos ištyrimas $(84,9 \%)$ bei akinių rèmo parinkimas ir pritaikymas $(81,4 \%)$, o naudojama iranga - autorefraktometras/autokeratorefraktometras $(98,8 \%)$, optotipų projektorius $(97,7 \%)$ ir dioptrimetras $(96,5 \%)$. Taip pat nustatyta, kad $63,5 \%$ optometrininkų per darbo dieną konsultuoja 1-5 pacientus, o $72,9 \%$ respondentų konsultacijai užtrunka $16-30 \mathrm{~min}$. Be to, didžioji dalis laiko (6,31 val./d.) darbo metu skiriama tiesioginems pareigoms vykdyti, t.y. akių ir regos tyrimams, konsultacijoms bei regos korekcijos kortelių išrašymui. Beveik puse $(41,9 \%)$ optometrijos paslaugas teikiančių respondentų lokalizuota Vilniaus savivaldybėje. 83,7\% respondentų nurodè, kad jų pacientai nuo registracijos iki paslaugos suteikimo laukia mažiau nei 1 dieną. Respondentų pasiskirstymo pagal naudotus kintamuosius ir darbo stažą bei gyvenvietès tipą palyginimas atskleide, jog statistiškai reikšmingai skyrèsi tik akinių pardavimas, vairuotojų regos patikra, subjektyvios refrakcijos ištyrimas, foropterio naudojimas, regos korekcijos kortelių išrašymas ir darbas kasos aparatu $(\mathrm{p}<0,05)$.

Išvados. Lietuvos optometrininkų profesinè darbo patirtis nèra didelè, todèl optometrijos paslaugų teikimo organizavimas nepakankamai optimizuotas efektyvios veiklos užtikrinimui. Optometrinès priežiūros paslaugos yra ribotai prieinamos Lietuvos gyventojams.

\section{Ivadas}

Lietuvoje optometrinè priežiūra ịdiegta ị sveikatos apsaugos sistemą nuo 2018 m. lapkričio 1 d., įsigaliojus Lietuvos Respublikos sveikatos apsaugos ministerijos patvirtinai Lietuvos medicinos normai MN 166:2018 „Optometrininkas“ (isakymas Nr. V-813) [1]. Šioje normoje optometrininkas yra ìvardijamas kaip asmens sveikatos priežiūros specialistas, teisès aktų nustatyta tvarka ịgijęs optometrininko profesinę kvalifikaciją. Optometrininko praktika - teisès aktų reglamentuota optometrininko pagal igytą profesinę kvalifikaciją ir nustatytą kompetenciją vykdoma suaugusių asmenų optometrinè priežiūra. Optometrinè priežiūra - asmens sveikatos priežiūros dalis, apimanti regos, akies refrakcijos ir jos pakitimų tyrimą, korekciją akiniais ir (ar) kontaktiniais lęšiais ir akinių ir (ar) kontaktinių lęšių skyrimo kortelių išrašymą. Optometrijos specialistų svarba akių sveikatos priežiūroje yra didžiulè, turint omenyje, kad globaliu mastu regos sutrikimų turi apie 1,3 milijardai žmonių [2, 3]. Pagrindines regos sutrikimo priežastis sudaro nekoreguotos refrakcijos ydos (miopija, hiperopija, presbiopija, astigmatizmas) ir neoperuotos kataraktos bei tokios lètinès akių ligos kaip 
glaukoma [3, 4]. Optometrininkų veiksmingumas bei nauda akių sveikatos priežiūroje, ypač kataraktos ir glaukomos prevencijoje, yra pagrįstas studijomis, vykdytomis Jungtineje Karalystėje (JK) [5]. Tačiau tyrimų, įvertinančių optometrinès priežiūros situaciją Lietuvoje, nèra atlikta, nepaisant to, kad optometrininkai mūsų šalyje praktikuoja jau daugiau nei 12 metų.

Darbo tikslas - ịvertinti optometrinès priežiūros paslaugų organizavimo ir prieinamumo Lietuvoje ypatumus.

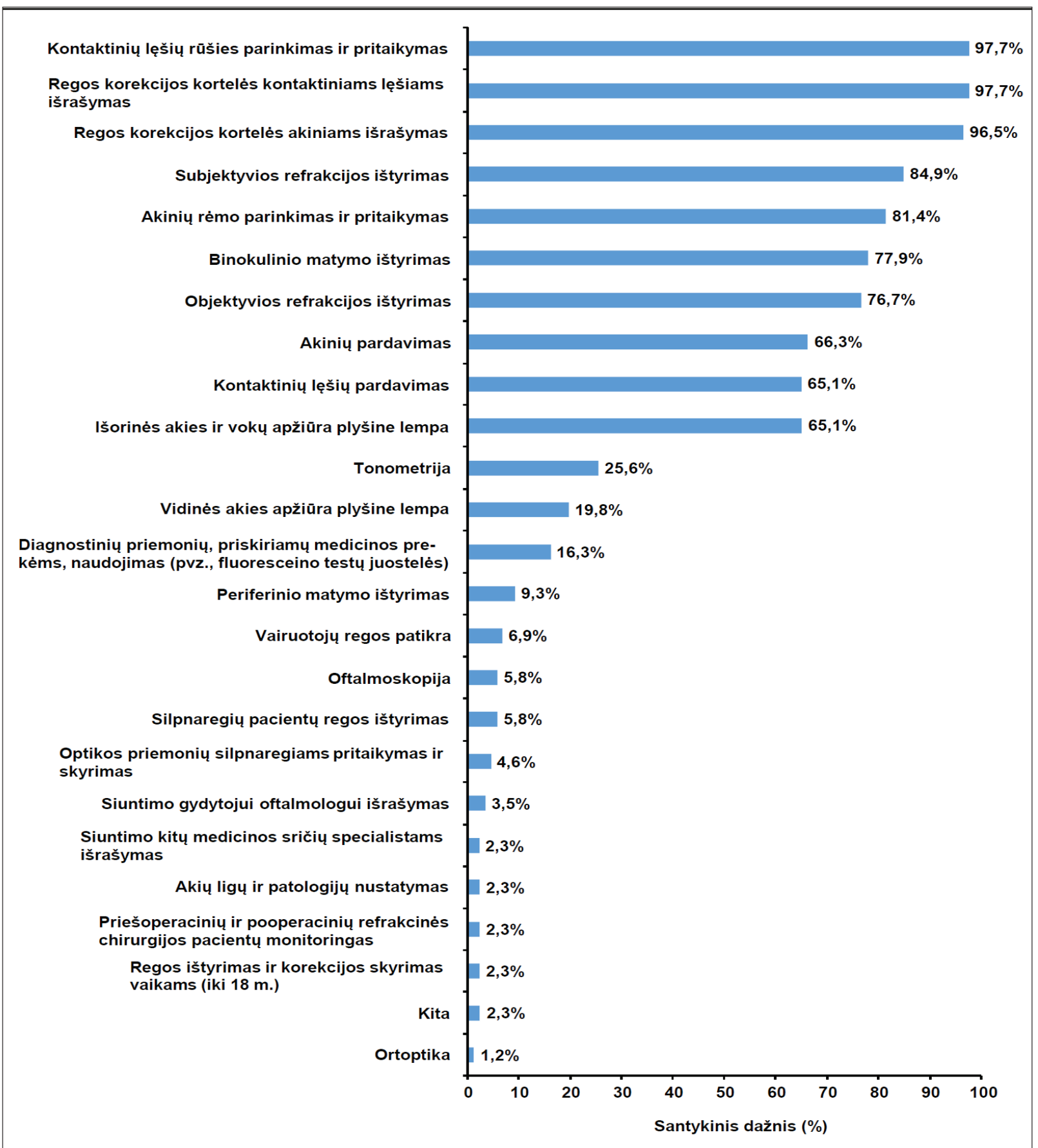

1 pav. Respondentų pasiskirstymas pagal teikiamų optometrinès priežiūros paslaugų dažnumą. 


\section{Tyrimo medžiaga ir metodai}

Tyrimo tikslinę populiaciją sudare Lietuvoje praktikuojantys optometrininkai. Tikslus jų skaičius nėra žinomas todèl, kad nèra oficialaus optometrininkų registro. Šiaulių universitetas - vienintelè edukacinè institucija, kuri nuo 2003 m. iki 2018 m. yra paruošusi apie 300 optometrininkų. Tiksliausi optometrininkų duomenys yra sukaupti Lietuvos optometrininkų asociacijoje (LOA). Anketinès apklausos vykdymo metu LOA buvo užsiregistravę 134 asmenys. Atsižvelgiant ị tai, kad LOA nariai sudare apie pusę Lietuvoje dirbančių optometrininkų, nuspręsta, būtent, juos įtraukti i tyrimą. Apskaičiuotas imties dydis - 100 respondentų buvo nustatytas naudojant Imties dydžio skaičiuoklę, parinkus $95 \%$ reikšmingumo lygmenị ir paklaidos ribą $\pm 5 \%$ [6]. Kaip instrumentas buvo naudojamas JK Optometrininkų koledžo parengtas standartizuotas klausimynas, modifikuojant ir pritaikant ji šiam tyrimui [7]. Apklausa vykdyta nuo 2019-02-04 iki 2019-02-25, kuomet 134 respondentams buvo išsiųsta internetinè nuoroda ị Google elektroninę anketos formą [8]. Iš viso buvo užpildytos ir pateiktos analizei 86 respondentu anketos, t.y. grįžtamumas sudare $64,2 \%$. Analizei pateiktose anketose: $48,8 \%$ respondentų nurodytas darbo stažas buvo
6-10 m., 29,1\% - iki $5 \mathrm{~m}$. ir $22,1 \%$ - daugiau nei $10 \mathrm{~m}$. Taip pat $82,6 \%$ respondentų nurodyta pagrindinè darbo vieta buvo didmiestis (Vilnius, Kaunas, Klaipeda), 14\% - rajono centras ir 3,4\% - seniūnija. Duomenų statistinè analizė atlikta panaudojant SPSS programinę įrangą (23.0 versija). Respondentu pasiskirstymo pagal darbo stažą bei gyvenvietès, kurioje teikia savo paslaugas, tipą palyginimui buvo naudotas Pirsono (Pearson) chi kvadrato kriterijus, kai 80\% ir daugiau prognozuojamų reikšmių buvo didesnès nei 5 . Kai daugiau nei $20 \%$ prognozuojamų reikšmių buvo mažesnès nei 5, naudotas Fišerio (Fisher) tikslusis testas. Rezultatų skirtumai laikyti statistiškai reikšmingais, kai $p<0,05$. Kadangi daugiau nei $95 \%$ respondentų nurodè, kad teikia savo paslaugas privačiame sektoriuje, t.y. optikos salonuose, tai šie klausimai nebuvo ịtraukti ị palyginamają analizę pagal minètus kintamuosius bei patys nenaudoti palyginamujų grupių sudarymui. Tolydžiųų kintamujų skirstinių normalumas tikrintas Šapiro Vilko (Shapiro-Wilk) testu. Pagal normaly skirstini pasiskirsčiusiems skirstiniams apskaičiuoti vidurkiai ir standartiniai nuokrypiai, o pagal normalų skirstini nepasiskirsčiusiems skirtiniams apskaičiuotos medianos bei pirmieji ir tretieji kvartiliai. Pagal normalujj skirstini

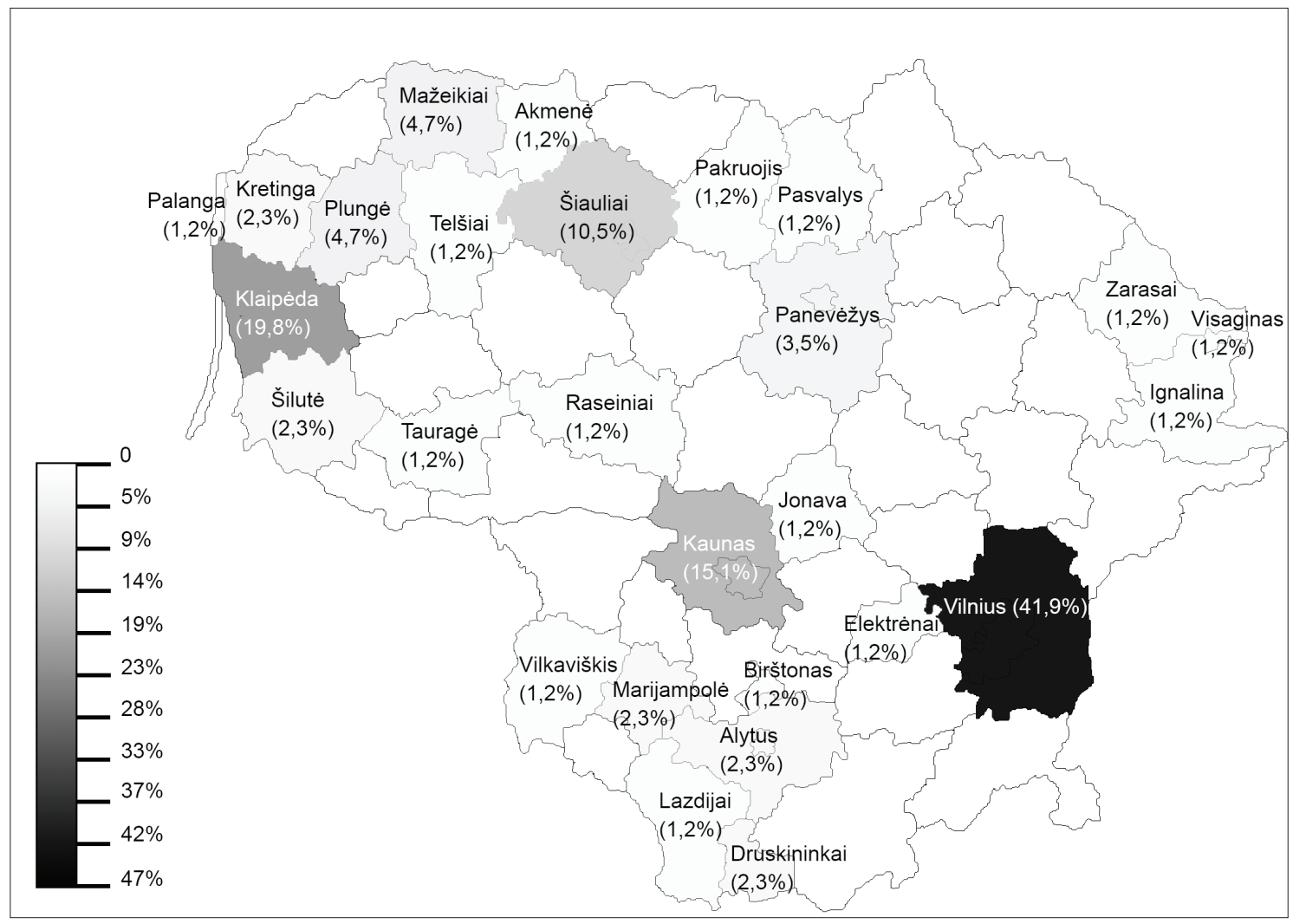

2 pav. Optometrinės priežiūros paslaugų teikimo Lietuvos savivaldybėse pasiskirstymas. 
pasiskirsčiusių tolydžiųjų kintamųjų reikšmių palyginimui naudotas Stjudento (Student) t-testas, o normalumo sąlygos netenkinančių kintamujų palyginimui naudotas Mano Vitney (Mann-Whitney) U testas.

\section{Tyrimo rezultatai}

Optometrinès priežiūros paslaugų organizavimo Lietuvoje ịvertinimas. Respondentų atsakymai ị klausimą „Kokias optometrinès priežiūros paslaugas Jūs teikiate?“ atskleidè, jog Lietuvoje dažniausiai teikiamos optometrinès priežiūros paslaugos yra kontaktinių lęšių rūšies parinkimas ir pritaikymas, regos korekcijos kortelių kontaktiniams lęšiams ir akiniams išrašymas, subjektyvios refrakcijos ištyrimas, akinių rèmo parinkimas ir pritaikymas, binokulinio matymo bei objektyvios refrakcijos ištyrimas (1 pav.).

Palyginus respondentų pasiskirstymą pagal teikiamų optometrinès priežiūros paslaugų dažnumą ir darbo stažą, nustatyta, kad statistiškai reikšmingai skyrėsi tik akinių pardavimas $(p=0,026)$ bei vairuotojų regos patikra $(p=0,007)$. Tuo tarpu, palyginus pagal gyvenvietės, kurioje teikia savo paslaugas, tipą, identifikuota, jog statistiškai reikšmingai skyrèsi tik subjektyvios refrakcijos ištyrimas $(p=0,046)$.

Respondentų atsakymų ị klausimą „Kokią optometrinę/ oftalmologinę ịrangą ir instrumentus Jūs naudojate, teikdami optometrinès priežiūros paslaugas?" analizè parodè, kad dažniausiai naudojami prietaisai optometrijos praktikoje yra autorefraktometras/ autokeratorefraktometras $(98,8 \%)$, optotipų projektorius $(97,7 \%)$ ir dioptrimetras $(96,5 \%)$. Santykinai rečiau teikiant optometrinès priežiūros paslaugas naudojami prietaisai - plyšinė lempa $(77,9 \%)$, foropteris $(40,7 \%)$ ir tonometras $(25,6 \%)$. Labai retai Lietuvoje optometrininkai naudoja perimetrą $(6,9 \%)$ ir oftalmoskopą $(5,8 \%)$ pacientų akių ir regos tyrimuose. Be to, beveik dešimtadalis respondentų $(9,3 \%)$ nurodè, kad naudoja ir kitą optometrinę/ oftalmologinę irangą bei instrumentus, t.y. pachimetrą, pupilometrą, optinį koherentinị tomografą, akies dugno (fundus) kamerą, optinį biometrą, keratografą, bandomuosius rèmelius ir lęšius. Palyginus respondentų pasiskirstymą pagal optometrinès/oftalmologinès įrangos ir instrumentų naudojimo dažnumą ir darbo stažą, statistiškai reikšmingo skirtumo nenustatyta $(p>0,05)$. Kita vertus, palyginus pagal gyvenvietès, kurioje teikia savo paslaugas, tipą, identifikuota, jog statistiškai reikšmingai skyrèsi tik foropterio naudojimas $(\mathrm{p}=0,003)$.

Respondentų atsakymai ị klausimą „,Kiek pacientų vidutiniškai Jūs konsultuojate per ịprastinę darbo dieną?" atskleidè, kad 63,5\% optometrininkų konsultuoja nuo 1 iki 5 pacientu per ịprastinę darbo dieną. $28,2 \%$ optometrininkų nurode, kad jie konsultuoja nuo 6 iki 10 pacientu, 7,1\% - nuo 11 iki 15 pacientų, o 1,2\% - daugiau nei 15 pacientų per darbo dieną.
Palyginus respondentų pasiskirstymą pagal konsultuojamų per darbo dieną pacientų skaičių ir darbo stažą, statistiškai reikšmingo skirtumo nenustatyta $(\mathrm{p}=0,927)$. Taip pat statistiškai reikšmingo skirtumo respondentų pasiskirstyme neidentifikuota ir palyginus pagal gyvenvietes, kurioje teikia savo paslaugas, tipą $(\mathrm{p}=0,617)$.

$72,9 \%$ respondentų atsakydami ị klausimą „Kiek ịprastai laiko Jūs užtrunkate vieno paciento konsultacijai?"“ nurodè, kad jie vieno paciento konsultacijai ịprastai užtrunka nuo 16 iki 30 min. 14,1\% respondentų nurodè, jog jie užtrunka nuo 31 iki 45 min., 10,6\% - iki 15 min. ir 2,4\% - nuo 46 iki 60 min. Palyginus respondentų pasiskirstymą pagal optometrinès konsultacijos trukmę ir darbo stažą, statistiškai reikšmingo skirtumo nenustatyta $(\mathrm{p}=0,228)$. Taip pat statistiškai reikšmingo skirtumo respondentu pasiskirstyme neidentifikuota ir palyginus pagal gyvenvietès, kurioje teikia savo paslaugas, tipą $(\mathrm{p}=0,467)$.

Respondentų atsakymai ị klausimą „Kiek valandų per dieną darbo metu Jūs skiriate savo veiklų vykdymui?" parodè, jog optometrijos specialistai darbo dienos metu daugiausiai laiko skiria akių ir regos tyrimams bei konsultavimui dèl medicinos priemonių (akinių rèmai, akinių lęšiai, dirbtinès ašaros ir pan.), t.y. atitinkamai po 3,36 $\pm 1,77$ val. ir 2 $(1-3,75)$ val. Mažesnę dali laiko, t.y. $0,95 \pm 0,88$ val. ir 0,5 $(0-1)$ val. per darbo dieną optometrininkai skiria atitinkamai tokioms veikloms kaip regos korekcijos kortelių išrašymas ir darbas kasos aparatu. Be to, respondentai nurodè, kad 1 $(0-1,88)$ val./d. darbo metu jie vykdo ir kitas veiklas, pvz., administruoja optikos veiklą, konsultuoja pacientus telefonu, dirba kompiuteriu, pildo prekių užsakymus, užsiima prekių išdėstymu bei tvarkos palaikymu. Palyginus respondentų pasiskirstymą pagal veiklų, atliekamų darbo metu, trukmę ir darbo stažą, nustatyta, kad statistiškai reikšmingai skyrèsi tik regos korekcijos kortelès išrašymas $(p=0,034)$ bei darbas kasos aparatu $(p=0,021)$. Tačiau palyginus pagal gyvenvietės, kurioje teikia savo paslaugas, tipą, statistiškai reikšmingo skirtumo nenustatyta $(\mathrm{p}>0,05)$.

Optometrinès priežiūros paslaugų prieinamumo Lietuvoje ịvertinimas. $41,9 \%$ respondentų atsakydami i klausimą „Kokioje Lietuvos savivaldybeje (ar keliose savivaldybėse) Jūs teikiate optometrinès priežiūros paslaugas?“ nurodè, kad jie šias paslaugas teikia Vilniuje, neišskiriant, ar tai miesto, ar rajono savivaldybė (2 pav.). Likusios dalies respondentų atsakymai dèl teikiamų optometrinès priežiūros paslaugų Lietuvos savivaldybėse pasiskirste tokiomis proporcijomis: 19,8\% - Klaipedos; 15,1\% - Kauno; 10,5\% - Šiaulių; po 4,7\% - Mažeikių ir Plungès; 3,5\% - Panevèžio; po 2,3\% - Alytaus, Druskininkų, Marijampolès, Kretingos ir Šilutès; po 1,2\% - Akmenès, Birštono, Elektrènų, Ignalinos, Jonavos, Lazdijų, Pakruojo, Palangos, Pasvalio, 
Raseinių, Tauragès, Telšių, Vilkaviškio, Visagino ir Zarasų. Be to, $18,6 \%$ respondentų nurode, jog jie teikia optometrinès priežiūros paslaugas ne vienoje, bet keliose Lietuvos savivaldybėse (pvz., Klaipėdos, Plungès ir Šilutès).

$83,7 \%$ respondentų atsakydami ị klausimą „Kiek vidutiniškai laiko Jūsų pacientas turi laukti nuo registracijos iki optometrinès priežiūros paslaugos suteikimo ịstaigoje, kurioje Jūs dirbate?" nurodè, kad jų pacientai turi laukti mažiau nei vieną kalendorinę dieną. 14\% respondentų atsakè, jog jų pacientai turi laukti 1-2 kalendorines dienas, o 2,3\% nuo 3 iki 5 kalendorinių dienų. Nei vienas iš respondentų nenurodè, jog pacientai turi laukti 6-7 dienas arba ilgiau nuo registracijos iki optometrinès priežiūros paslaugos suteikimo. Palyginus respondentų pasiskirstymą pagal laiką, kurị pacientams tenka laukti, ir darbo stažą, statistiškai reikšmingo skirtumo nenustatyta $(p=0,770)$. Taip pat statistiškai reikšmingo skirtumo respondentu pasiskirstyme nenustatyta ir palyginus pagal gyvenvietès, kurioje teikia savo paslaugas, tipą $(\mathrm{p}=0,051)$.

\section{Rezultatų aptarimas}

Šis tyrimas pirmą kartą Lietuvoje ịvertino optometrinès priežiūros paslaugų organizavimo ir prieinamumo ypatumus. Optometrinès priežiūros organizavimo aspektu, tyrimo rezultatai parodè, jog pusès iš apklaustų respondentų darbo stažas optometrininko pareigose yra nuo 6 iki 10 metų. Vadinasi, optometrijos specialistų sukaupta profesinè darbo patirtis santykinai nèra didelè. Tačiau reikia atsižvelgti ị tai, kad Lietuvoje optometrija yra dar pakankamai jauna specialybė - optometrininkai pradèti ruošti Šiaulių universitete nuo 2003 m. Kita vertus, darbo patirtis yra svarbus veiksnys, kuris siejasi su optometrinès priežiūros teikiamų paslaugu spektru, gebèjimu naudoti ịvairią optometrinę/oftalmologinę įrangą bei instrumentus praktikoje, konsultuojamų per darbo dieną pacientų skaičiumi, paciento konsultacijos trukme ir darbo metu atliekamų veiklų trukme. Vertinant tyrimo rezultatus šiais atžvilgiais, reikia pažymèti, kad Lietuvoje optometrininkai teikia pacientams daugumą tų paslaugų, kurias teikia ir kitų Europos Sajungos šalių optometrijos specialistai, t.y. kontaktinių lęšių rūšies parinkimas ir pritaikymas, regos korekcijos kortelių akiniams bei kontaktiniams lęšiams išrašymas, subjektyvios ir objektyvios refrakcijų ištyrimas, akinių rèmo parinkimas ir pritaikymas bei binokulinio matymo ištyrimas [9]. Su minètomis paslaugomis atitinkamai siejasi ir dažniausiai optometrijos specialistų praktikoje taikoma įranga bei instrumentai - autorefraktometras/autokeratorefraktometras, optotipu projektorius ir dioptrimetras. Tyrimo metu nustatyta, jog didžioji dalis optometrininkų per darbo dieną konsultuoja vidutiniškai nuo 1 iki 5 pacientų. Turint omenyje, kad darbo laikas yra
8 val./d., tai šis rodiklis nèra aukštas bei gali sietis su nepakankama darbo patirtimi. Nepaisant tokio nedidelio konsultuojamų pacientų skaičiaus, dauguma optometrininkų vieno paciento konsultacijai užtrunka nuo 16 iki 30 min., o tai yra optimali trukme pakankamai nuodugniam paciento akių ir regos ištyrimui. Tokiose šalyse kaip Jungtinė Karalyste (JK) ir Airija, kur optometrine priežiūra yra organizuota ypač gerai ir pacientams suteikiamas maksimalus paslaugu spektras, optometrininkai vieno paciento konsultacijai skiria vidutiniškai 30 min. [7, 9, 10]. Pažymėtina, kad optometrijos specialistai darbo metu didžiają laiko dali (6,31 val./d.) skiria savo tiesioginems pareigoms vykdyti, t.y. akių ir regos tyrimams, pacientų konsultavimui dẻl medicinos priemonių (pvz., akinių rèmai, akinių lęšiai, dirbtinès ašaros) ir regos korekcijos kortelių išrašymui. Visgi reikètų atkreipti dèmesị i tai, jog Lietuvoje optometrininkai darbo metu 1,5 val./d. skiria veikloms, kurios tiesiogiai nesusijusios su jų tiesioginemis funkcijomis - darbui kasos aparatu, optikos veiklos administravimui, prekių užsakymų pildymui, jų patikrai bei išdèstymui ir kt.

Optometrinès priežiūros paslaugų prieinamumo aspektu, tyrimo rezultatai atskleidè, kad Lietuvoje beveik visi optometrininkai $(98,8 \%)$ dirba privačiame sektoriuje, kuris daugiausia apima optikos salonus. Tai reiškia, kad Lietuvos gyventojams teikiamos optometrinès priežiūros paslaugos yra mokamos, ir todèl nèra prieinamos mažas pajamas gaunantiems žmonèms. Kita vertus, mokūs pacientai, kuriems šios paslaugas yra prieinamos, gali jas gauti per pakankamai trumpą laiką, nes didžioji dalis optometrininkų pažymėjo, jog jų pacientai turi laukti mažiau nei vieną kalendorinę dieną nuo registracijos iki optometrinès priežiūros paslaugos suteikimo. Pabrēžtina, kad dauguma respondentų nurodè savo pagrindinès darbovietės lokalizaciją - didmiestí, t.y. Vilnių, Kauną ir Klaipėdą. Vertinant tyrimo rezultatus Lietuvos savivaldybių atžvilgiu, būtent, Vilniaus, Kauno ir Klaipèdos savivaldybèse (neišskiriant ar tai miesto, ar rajono savivaldybė) yra sukoncentruota daugiausia optometrijos specialistų. Santykinai mažesnè dalis optometrininkų dirba šiose Lietuvos savivaldybėse: Šiaulių, Mažeikių, Plungès, Panevėžio, Alytaus ir kt. Reikètų atkreipti demesị i tai, kad beveik pusejje Lietuvos savivaldybių (t.y. 28 savivaldybès) optometrinès priežiūros paslaugos nèra teikiamos. Tačiau būtina akcentuoti tą faktą, kad visose Lietuvos savivaldybėse yra valstybinès poliklinikos ir ligoninès, kuriose dirbantys gydytojai oftalmologai bei šeimos gydytojai taip pat teikia akių ir regos sveikatos priežiūros paslaugas. Palyginus šiuos rezultatus su JK duomenimis, reikètų pabrèžti, kad šioje šalyje daugiau nei puse optometrininku (52,7\%) dirba kaip nepriklausomi praktikai, kita dalis $(32,7 \%)$ - valstybinèse institucijose, o maža dalis $(6,3 \%)$ - ligoninèse ir klinikose 
[7]. Be to, apytiksliai 30\% Jungtinès Karalystès optometrininkų pagrindinès darbovietės lokalizacija yra didmiestis, $60 \%$ - mažesni miestai ir 10\% - kaimo vietovès [7]. Taigi šiame kontekste Lietuva išsiskiria, nes didžioji dauguma optometrijos specialistų dirba didmiesčiuose ir išskirtinai tik privačiame sektoriuje.

\section{Išvados}

1. Lietuvos optometrininkų profesinè darbo patirtis nèra didelè, o tai turi neigiamą įtaką teikiamų optometrinès priežiūros paslaugų spektrui, kuris yra pakankamai platus, naudojamos optometrinès/oftalmologinès įrangos ir instrumentų pritaikymui akių bei regos tyrimuose, konsultuojamų per darbo dieną pacientų skaičiui, konsultacijos trukmei ir darbo laiko organizavimui.

2. Lietuvoje optometrinès priežiūros paslaugos teikiamos išskirtinai tik privačiame sektoriuje (t.y. optikos salonuose) ir lengviausiai prieinamos didmiesčiu gyventojams, tačiau ribotai prieinamos rajonų centruose ir seniūnijose gyvenantiems žmonėms bei neprieinamos beveik pusejje Lietuvos savivaldybių.

3. Lietuvoje būtina teikti daugiau optometrinès priežiūros paslaugu valstybiniame sektoriuje (pvz., poliklinikose), apimant rajonų centrus ir seniūnijas bei tas Lietuvos savivaldybes, kur jos apskritai nèra teikiamos.

\section{Literatūra}

1. Lietuvos Respublikos sveikatos apsaugos ministerija. Lietuvos medicinos norma MN 166:2018 "Optometrininkas" (isakymas Nr. V-813). Teisès aktų registras, 2018-06-26; 12466:1-6.

2. Woo GC, Woo SY. The need for full scope primary care eye care in every country. Clin Exp Optom 2013; 96(1):1-3. https://doi.org/10.1111/j.1444-0938.2012.00774.x

3. World Health Organization. Blindness and vision impairment. Fact sheets [žiūrèta 2019-03-13]. Prieiga per internetą: $<$ https:// www.who.int/news-room/fact-sheets/detail/blindness-andvisual-impairment>.

4. Bourne RRA, Flaxman SR, Braithwaite T, Cicinelli MV, Das A, Jonas JB. et al. Vision Loss Expert Group. Magnitude, temporal trends, and projections of the global prevalence of blindness and distance and near vision impairment: a systematic review and meta-analysis. Lancet Glob Health 2017; 5(9):e888-897.

5. Baker H, Ratnarajan G, Harper RA, Edgar DF, Lawrenson JG. Effectiveness of UK optometric enhanced eye care services: a realistic review of the literature. Ophthalmic Physiol Opt 2016; 36(5):545-557. https://doi.org/10.1111/opo.12312

6. Apklausos.LT. Imties dydžio skaičiuoklè [žiūrèta 2019-02-01]. Prieiga per internetą: $<$ http://www.apklausos.lt/imties-dydis $>$.

7. The College of Optometrists. The optical workforce survey [žiūrèta 2018-09-03]. Prieiga per internetą: <https://www. college-optometrists.org/uploads/assets/uploaded/ b8034532ce20-4e5d-8792039e270a34d1.pdf>.
8. Google forma: Optometrinè priežiūra Lietuvoje [sukurta 2019-01-14]. Prieiga per internetą: <https://goo.gl/forms/ AVprmQj9w CEAEsOl1>.

9. European Council of Optometry and Optics. ECOO Blue Book: Data on optometry and optics in Europe. European Council of Optometry and Optics, Brussels, Belgium, 2017; 1-28.

10. Barrett C, Loughman J. Expanding the traditional role of optometry: Current practice patterns and attitudes to enhanced glaucoma services in Ireland. J Optom 2018; 11(4):252-261. https://doi.org/10.1016/j.optom.2018.02.004

\section{PECULIARITIES OF OPTOMETRIC CARE ORGANIZATION AND ACCESSIBILITY IN LITHUANIA}

V.Kačergienė, F.Stepukonis, S.Norkienė

Keywords: personal health care, optometry, optometrist, optometric care, optometric services.

Summary

Aim of the work - to evaluate the peculiarities of optometric care organization and accessibility in Lithuania.

Methodology of the work. The instrument used for research electronic questionnaire, to which the link was sent for respondents by using e-mail. The subject sample (134 respondents) consisted of optometrists, registered at the Lithuanian Association of Optometrists. A total of 86 respondents' questionnaires were filled out and submitted for analysis, i.e. reversibility was $64.2 \%$. Half of the respondents $(48.8 \%)$ had $6-10$ years of work experience. The majority of respondents indicated location of the main workplace - large cities (Vilnius, Kaunas, Klaipeda), and more than $95 \%$ - provide services in the private sector (i.e. in optics). Statistical analysis of data was carried out using SPSS software (version 23.0). Differences in results were considered statistically significant, when $\mathrm{p}<0.05$.

Results. It was determined that the mostly provided optometric care services in Lithuania are selection and fitting of contact lenses' type $(97.7 \%$ ), prescription of contact lenses and spectacles (respectively $97.7 \%$ and $96.5 \%)$, subjective refraction $(84.9 \%)$ and selection and fitting of spectacle frames (81.4\%), as well as the mostly used equipment - auto refractometer/auto kerato-refractometer (98.8\%), optotype projector $(97.7 \%)$ and diopthrimeter $(96.5 \%)$. It was also found that $63.5 \%$ of optometrists consult $1-5$ patients during workday, and $72.9 \%$ of respondents take $16-30 \mathrm{~min}$ for the consultation. In addition, most of the time $(6.31 \mathrm{~h} / \mathrm{d})$ during work are allocated the direct duties, i.e. eye and vision examinations, consultations and prescriptions for vision correction. Almost half (41.9\%) of the respondents providing optometric services are located in Vilnius municipality. $83.7 \%$ of the respondents indicated that their patients wait less than 1 day from registration to the provision of service. Comparison of the respondents' distribution by the used variables and work experience and the type of settlement revealed that there was only a statistically significant difference in the sale of spectacles, testing of drivers' vision, subjective refraction, use of phoropter, prescriptions for vision correction and work with a cash register $(\mathrm{p}<0.05)$.

Conclusions. The professional work experience of the Lithuanian optometrists is not high, therefore the organization of optometry service provision is not sufficiently optimized to ensure effective activities. Optometric care services are limited to residents of Lithuania.

Correspondende to: vaida.kacergiene@gmail.com

Gauta 2019-04-30 